VIRTUAL FREEDOM 



\title{
VIRTUAL FREEDOM
}

Net Neutrality and Free Speech

in the Internet Age

\author{
Dawn C. Nunziato
}

STANFORD LAW BOOKS

An Imprint of Stanford University Press

Stanford, California 
Stanford University Press

Stanford, California

(C) 2009 by the Board of Trustees of the

Leland Stanford Junior University

All rights reserved.

No part of this book may be reproduced or transmitted in any form or by any means, electronic or mechanical, including photocopying and recording, or in any information storage or retrieval system without the prior written permission of Stanford University Press.

Printed in the United States of America on acid-free, archival-quality paper

Library of Congress Cataloging-in-Publication Data

Nunziato, Dawn C.

Virtual freedom : net neutrality and free speech in the Internet age / Dawn C.

Nunziato.

p. $\mathrm{cm}$.

Includes bibliographical references and index.

ISBN 978-0-8047-5574-o (cloth : alk. paper)-ISBN 978-0-8047-6385-1

(pbk. : alk. paper)

1. Freedom of speech-United States. 2. Internet-Censorship-United States.

3. Internet-Law and legislation-United States. I. Title.

KF4772.N86 2009

$342.7308^{\prime} 53-\mathrm{dc} 22$

2009012532

Designed by Bruce Lundquist

Typeset by Classic Typography in 10/14 Minion 
To my wonderful children, Allie and Zachmay you always be free to express yourselves to my husband, Jon, my favorite author-for leading the way and to my parents, Frances and Joseph-for always believing in me 

"[W]e could be witnessing the beginning of the end of the Internet as we know it."

-Michael J. Copps, FCC commissioner, "The Beginning of the End of the Internet?" New America Foundation, Washington, D.C., October 9, 2003

"The potential for abuse of this private power over a central avenue of communication cannot be overlooked. ..."

-Turner Broadcasting System, Inc. v. F.C.C., 512 U.S. 622, 657 (1994)

"When we balance the constitutional rights of owners of property against those of the people to enjoy [First Amendment freedoms], . . . we remain mindful of the fact that the latter occupy a preferred position."

-Marsh v. Alabama, 326 U.S. 501,509 (1946) 
